\title{
REFERENCES
}

ECKEL, L. H. 1953. The Hatchet Planimeter. Forestry Chronicle, Vol. 29, No. 3.

KRAMER, P. R. and STURGEON, E.E. 1942. Transect method of estimating area from aerial photography index sheets. Journal of Forestry, Vol, 40, No. 9.

LOETSCH, F, and HALLER, E, 1962. The adjustment of area computations from sampling devices on aerial photographs. Photogrammetric Engineering, Vol. XXVIII, No. 5.

NASH, A. J. 1948. A photoelectric planimeter. Surveying and Mapping, Vol. VIII, No. 2.

RIDEOUT, E. E. 1962. Measurement by the MK area calculator. Department of Forestry, Canada, Forest Research Branch. Report 62-19.

SNEDECOR, G. W. 1959. Statistical methods (fffth edition). The Iowa State College Press, Ames, Iowa.

SPURR, S. H. 1948. Aerial photographs in forestry. Ronald Press Co., New York.

WINKWORTH, A. V. 1956. A comparison of methods employed in measuring area. University of British Columbia. Research Note No. 15.

Figure 1 for page 184

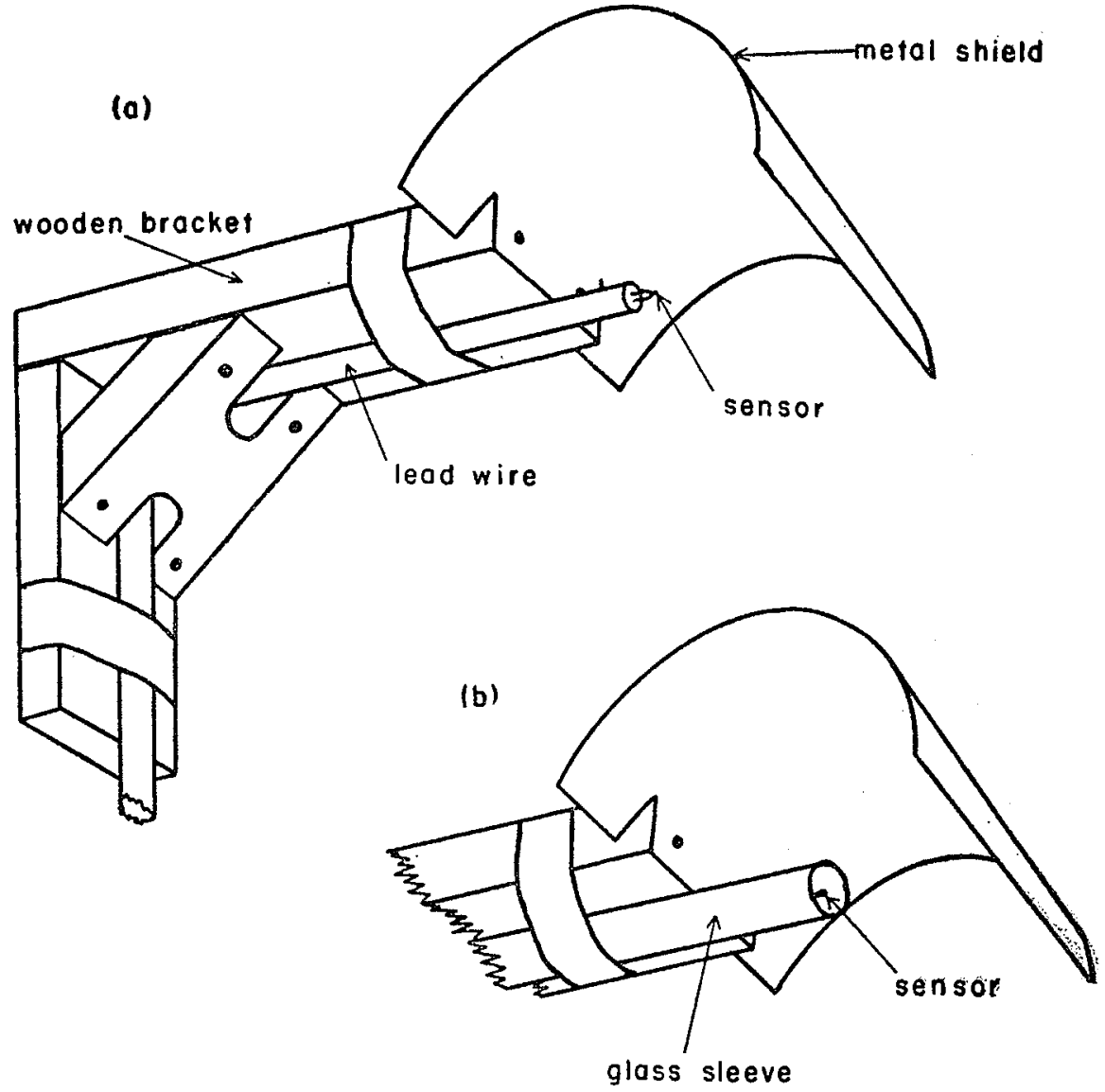

FIGURE 1. Metal shield - glass sleeve protection of thermocouple sensor against radiational errors. Both shield and sleeve are coated with non-hygroscopic white paint. 


\section{A PRACTICAL THERMOCOUPLE SHIELD ${ }^{1}$}

\section{By GY. PECH ${ }^{2}$}

In bioclimatological research investigators often wish to measure temperature in confined spaces. Sensors used to measure air temperature must be shielded from both direct and indirect solar radiation to avoid radiational errors, frequently of considerable magnitude (Bowden 1958). In micro-environmental research, sensors and their shields must be small, compact and adaptable for use with remote recording instruments. Adequately shielded thermistors or thermocouples used with resistance meters satisfy these criteria, and can be placed at any height above the ground.

During the summers of 1960 and 1961 vertical distributions of air temperature were measured in a conifer stand at the Petawawa Forest Experiment Station, Chalk River, Ontario, using 20-guage copper-constantan thermocouples and two Leeds \& Northrup single-range potentiometers. An inexpensive, lightweight shield was constructed to protect the sensor from radiation.

"Can" shelters, designed initially for Six's thermometers by Fraser (1961), were modified by cutting the tin cylinder in half, painting it white, and nailing the shield on a wooden bracket (Fig 1a). Protection afforded by this halfcan shield against direct horizontal solar radiation in the early morning and in the late afternoon, and against indirect radiation throughout the day was inadequate. Deviations as great as $5-6^{\circ} \mathrm{F}$. still occurred. To overcome these errors, a white-painted glass sleeve, $10 \mathrm{~mm}$ in diameter, was placed over the thermocouple and fastened to the bracket with electric tape (Fig. 1b).

The aim of subsequent field trials was twofold. i.e. to determine the error $\left({ }^{\circ} \mathrm{F}\right.$.) attributable to:

(a) The interference of glass sleeve with free air circulation around the sensor;

(b) Indirect solar and direct terrestrial radiation striking the partly shielded sensor.

Three thermocouples were mounted on brackets in an open field 48 inches above short-cut grass. One was shielded against direct solar radiation with the half-can metal shield only, while the other two thermocouples had glass sleeves projecting 1-2 $\mathrm{mm}$ and $5-6 \mathrm{~mm}$ beyond the sensors in addition to metal shielding. Temperatures at the two latter junctions were measured at halfhourly intervals on a clear day in June, 1960, with a Leeds \& Northrup potentiometer; also, for reference, temperature was read from a sling psychrometer at half-hour intervals. Throughout the day a light breeze (1-3 m.p.h.) prevailed

\footnotetext{
${ }^{1}$ Department of Forestry, Canada, Forest Research Branch Contribution No. 574.

${ }^{2}$ Formerly Research Officer, Forest Research Branch, Department of Forestry; presently postgraduate in Agro-Meteorology, School of Graduate Studies, University of Toronto, Toronto, Ont.
}

Figure 1 is on page 183 
on the site at thermocouple level. While a representative reading of the air temperature would require "an air flow of between 2.5 and $10 \mathrm{~m} / \mathrm{sec}$. $(6-22$ m.p.h., past the thermometer bulb" (W.M.P. 1961, p IV. 2), the prevailing light breeze resembled more closely the low wind velocities commonly experienced in forest stands (Geiger 1957)

The results (Table 1) show a $\pm 1.2^{\circ} \mathrm{F}$. deviation from the standard reference temperature on the morning and during the day for the sensor surrounded by stagnating air (column 3 ). The $1-2 \mathrm{~mm}$ sleeve projection appears to provide adequate shielding against solar and terrestrial radiation without hindering air circulation around the sensor.

TABLE 1

Air Temperature Measurements At 48 Inches Above Short-Cut Grass In The Open, Using Two Thermocouples Under Half-Can Glass Sleeve

Shields, And a Sling Psychrometer. Clear Sky, Light Breeze (1-3 M.P.H.), JUNE 23, 1960

\begin{tabular}{cccc}
\hline $\begin{array}{c}\text { Time } \\
\text { (E.S.T.) }\end{array}$ & $\begin{array}{c}\text { Sling } \\
\text { temperature } \\
\left({ }^{\circ} \mathbf{F} .\right)\end{array}$ & $\begin{array}{c}\text { Thermocouple temperature } \\
\text { Sleeve projection beyond } \\
\text { s-2 } \text { smm }^{\circ} \text { ) } \\
\mathbf{5 - 6} \text { mm }\end{array}$ \\
\hline 0900 & 68 & 68 & 66 \\
0930 & 70 & 70 & 69 \\
1000 & 75 & 75 & 75 \\
1030 & 76 & 76 & 77 \\
1100 & 77 & 77 & 78 \\
1130 & 78 & 78 & 79 \\
1200 & 78 & 78 & 79 \\
1300 & 78 & 78 & 79 \\
1330 & 79 & 79 & 80 \\
1400 & 80 & 79 & 80 \\
1430 & 81 & 81 & 83 \\
1500 & 80 & 80 & 82 \\
1530 & 80 & 80 & 81 \\
1600 & 79 & 79 & 80 \\
\hline
\end{tabular}

To secure values for (b), an electric multi-point recorder (accurate to $\pm 0.25^{\circ} \mathrm{F}$.) was connected to the three thermocouples in 1961. It provided 56 temperature measurements hourly at each of the junctions. Calculated hourly mean daytime temperatures are shown (Table 2) for a clear day in June. Wind velocities were low, 1-2 m.p.h. at thermocouple level.

A comparison of temperatures in the first two columns (Tab 2) indicates that inadequate shielding against indirect solar and direct terrestrial radiation may cause an error of between 0.5 and $1.0^{\circ} \mathrm{F}$. in air temperature measurements. Confirming the earlier result, an increase of $0.5-2.0^{\circ} \mathrm{F}$. from true air temperature is apparent for the third thermocouple around which the air was stagnant in the long sleeve.

Accepting a 1-2 $\mathrm{mm}$ sleeve projection as adequate, the shield performs satisfactorily regardless of horizontal orientation. Its lightness facilitates handling and installation from ground level (c.f. Portman 1954) to the top of tree crowns. 
TABLE 2

Comparison Of Shielding Methods. Atr Temperature Measured With Thermocouples Under Half-Can Metal Shield (A), Metal Shield Plus

Glass Sleeve Projecting 1-2 mM (B), And 5-6 mM (C) Beyond The Sensors. Clear Sky, Light Breeze (1-2 M.P.H.) At

THermocouple LeVEl, MEAN OF 56 HOURLY Measurements For EAch Junction, June 27, 1961

\begin{tabular}{cccc}
\hline $\begin{array}{c}\text { Time } \\
\text { (E.S.T.) }\end{array}$ & A & $\begin{array}{c}\left.\text { Air temperature (' }{ }^{\circ} \text {. }\right) \\
\text { Type of shielding } \\
\text { B }\end{array}$ & C \\
\hline $0900-1000$ & 72.0 & 71.5 & 72.5 \\
$1000-1100$ & 77.0 & 76.5 & 78.0 \\
$1100-1200$ & 79.5 & 79.0 & 80.5 \\
$1200-1300$ & 81.0 & 80.5 & 82.0 \\
$1300-1400$ & 82.5 & 81.5 & 83.5 \\
$1400-1500$ & 83.5 & 83.0 & 85.0 \\
$1500-1600$ & 84.0 & 84.5 & 85.0 \\
$1600-1700$ & 86.5 & 85.5 & 86.0 \\
$1700-1800$ & 83.5 & 82.0 & 83.5 \\
\hline
\end{tabular}

REFERENCES

BOWDEN, B. N. 1958. The radiation error of air temperature measurement by Stantel Type $F$ thermistors and simple methods to reduce it. J. Ecol. 46:143-148.

FRASER, J. W. 1961. A simple shelter for Six's thermometers. For. Chron. 37(4):318-322.

GEIGER, R. 1957. The climate near the ground. 2nd ed., Harvard Univ. Press, Cambridge. PORTMAN, D. J. 1954. The measurement of air temperature profiles. Publ. in Climatology $7(2): 250-260$

World Meteorological Organization 1961. Guide to Meteorological Instrument and Observing Practices. 2nd ed., No. 8, TP. 3, Geneva. 